\title{
HIGH OCCURRENCE OF GIARDIASIS IN CHILDREN LIVING ON A 'LANDLESS FARM WORKERS’ SETTLEMENT IN ARARAS, SÃO PAULO, BRAZIL
}

\author{
Oswaldo Aparecido de LIMA JUNIOR, Juliana KAISER \& Rosana CATISTI
}

\begin{abstract}
SUMMARY
Enteric parasitosis remains an important public health problem in many areas around the world including in Brazil, and it is frequently associated with poverty and lack of sanitation facilities. Research carried out over the course of a year revealed that $96.6 \%$ (28/29) of children randomly selected from a 'landless farm workers' settlement in Araras, São Paulo, aged 4 - 15 years, presented Giardia intestinalis cysts. After referral to the neighborhood Health Office, all the children received tinidazole, given as a single dose of $50 \mathrm{mg} / \mathrm{kg}$ and 12 months later, new fecal samples were collected and analyzed. Despite the low adherence to the study, a high percentage $(64.3 \%$ - 9/14) of the children remained positive for the parasite. This study showed a high positivity of giardiasis in child residents of the settlement, even after treatment; adults were not sensitized to the study and did not collected and/or deliver children fecal samples. The precarious living conditions are consistent with a high susceptibility to parasitic diseases, suggesting that the treatment of the infected individuals without identifying and eradicating the means of contamination is simply a palliative measure.
\end{abstract}

KEYWORDS: 'Landless farm workers' settlement; Giardiasis; Giardia intestinalis; Parasitic infections; Public health.

\section{INTRODUCTION}

Parasitic diseases are seen as indicators of the socio-economic development of a country and are a frequent public health problem mainly affecting young adults, as well as triggering gastrointestinal problems, poor performance and a consequent delay in scholastic development. Although efforts by health agencies worldwide to control these diseases are not measured, there has been no reduction in rates, especially in lowincome families whose precarious living conditions, poor hygiene and nutrition also contribute to the spread of parasitic diseases ${ }^{14}$. In developing countries, giardiasis is a common cause of diarrhea among children, who as a result of the infection often have problems with malnutrition and delayed development. Giardiasis has a different clinical aspect, ranging from asymptomatic to symptomatic patients who may present acute selflimiting diarrhea or persistent diarrhea, with evidence of malnutrition and weight loss. Transmitted through the ingestion of Giardia intestinalis cysts, giardiasis is distributed worldwide and is considered to be the main cause of outbreaks of diarrhea originating from contamination of water reservoirs ${ }^{1}$, through food or person to person contact. It is often possible even among the asymptomatic cases to demonstrate evidence of malnutrition, therefore impairing the nutritional status ${ }^{15}$. The goal of this research was to verify the occurrence of giardiasis in children living on a 'landless farm workers' settlement in Araras, São Paulo (SP) and to check the recurrence of the disease after treatment.

\section{EXPERIMENTAL METHODS}

This study was conducted in "Araras 2", Araras City, SP with 14 plots of land spread out over 2089,900 square meters, located on the east side of town between the urbanized periphery and the rural area. This community inhabited by 14 families carries out agricultural activities in a region lacking basic sanitation, which is conducive to the emergence of diseases caused largely by parasites. All children (between four and 15 years) of both genders $(n=50)$ randomly selected were enrolled in this study. The criteria for the selection of the children were age and the consent term, approved by the Ethics Committee on Human Research, UNIARARAS, no. 365/2005 and signed by their parents or guardians. Together with the feces collectors, instructions and precautions were distributed to be observed during the sample collection, and a questionnaire on social-economic demographics was carried out. Out of the 50 bottles delivered to the research participants, 29 (58.0\%) samples were received and immediately sent to the Laboratory of Parasitology for parasitological examination. LUTZ ${ }^{10}$ and FAUST $^{6}$ techniques were used to study the intestinal parasite. After analysis, the results were delivered to the parents or guardians of the children, and the positive cases were referred to the district public health center for treatment with tinidazole, given as a single dose of $50 \mathrm{mg} / \mathrm{kg}$. After one year, the collection of fecal material was requested again, but only 14 of 29 (48.3\%) samples were sent for analysis.

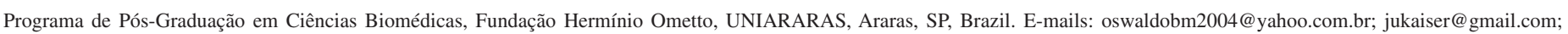
rosanacatisti@uniararas.br 


\section{RESULTS}

The answers to the social-economic demographics questionnaire showed that, with regard to education, the parents had completed basic education; they do not have private health insurance, but all children have vaccination records. As for housing, $41.37 \%$ of houses are constructed out of canvas. Only $34.48 \%$ of households receive water, while $62.06 \%$ have electricity. Most of the garbage is not collected, but burned in the backyard or disposed of in the wasteland. The families do not grow vegetable gardens. They have domestic animals (86.20\%), and most are vaccinated $(75.86 \%)$. With regard to the animals, $20.68 \%$ remain indoors. They are distributed between dogs (86.20\%), horses (13.79\%), cats $(6.89 \%)$, cows, chickens and pigs $(3.44 \%)$.

Of the 29 samples analyzed, 28 (96.6\%) were positive for some kind of parasite, $10(35.7 \%)$ had one parasite species, while infections by more than one parasite species occurred in 18 (64.3\%). Of the species observed, G. intestinalis was the most frequent (96.6\%), followed by Entamoeba coli (27.6\%), Endolimax nana (13.8\%) and Iodamoeba butschlii $(3.4 \%)$ (Table 1). Among the helminths, hookworms were present in two cases $(6.9 \%)$ and each one of the following species in one case (3.4\%): Hymenolepis nana, Trichuris trichiura, Ascaris lumbricoides and Strongyloides stercoralis (Table 1). After one year, 12 (85.7\%) of the 14 stool samples analyzed were positive for some type of parasite, while two $(14.3 \%)$ were negative. Of the 12 children who had positive stool samples, nine $(75 \%)$ showed a single parasite, while three $(25 \%)$ presented more than one parasite species. G. intestinalis was present in $64.3 \%$, E. nana in $21.5 \%$ and A. lumbricoides in $7.1 \%$ (Table 1). The positivity did not differ among different age groups between the two study periods. Children aged four to seven and eight to 11 years showed a reduction in the positivity of $92.3 \%$ and $100 \%$ in 2005 to $83.3 \%$ and $80 \%$ in 2006, respectively. Children from 12 to 15 years showed no change in the positivity rate (100\% in 2005 and 2006). As shown in Table 1, G. intestinalis had high positivity $(96.6 \%)$ in 2005, declining in 2006 but still remaining high $(64.3 \%)$ considering that these children received medication donated by the neighborhood Health Center after the delivery of the report with the results of the examinations.

\section{DISCUSSION}

This study was based on a sample from an underprivileged population in which a high prevalence of giardiasis was largely observed when compared to studies done in other cities in Brazil ${ }^{4,5,7-13,16-19}$. It is part of an "Extension Project to the Community" where two undergraduate students voluntarily worked on weekends, trying to make the community aware of the importance of health care. The lack of statistical data and the small number of samples analyzed due to poor adherence of the population to the study makes this work limited, but our biggest goal is to alert the scientific community to the existence of high disease levels. Upon delivery of fecal collectors, the authors sought to sensitize parents and/or guardians to the importance of stool tests in the diagnosis of parasitic diseases. Although all of the children from the community were enrolled in this study, the number of samples analyzed was small, but it was representative (29/50 - 58.0\%) of the population studied. The lower compliance in the first stage of the study reflects the tendency of the general population to disregard health, which was confirmed in the second phase of the study after treatment. The occurrence of intestinal protozoa is an important bioindicator for the persistence of unhygienic behavior of the population in the camps and continual water contamination by human feces that may also increase the risk of contracting other infectious diseases. This information can be useful for monitoring compliance with community health and hygiene programs carried out in the camps. It may also indicate the need to intensify educational efforts for the prevention of diarrhea associated with enteric pathogens that cannot be controlled by drugs alone ${ }^{12}$.

The poor sanitation conditions expose people to the acquisition of different pathogens, causing frequent cases of multiple parasitism. A recent report ${ }^{8}$ from the city of Uberlândia, MG, shows a positivity of $29.3 \%$ for enteric parasites: $G$. intestinalis was the most frequent and the only pathogenic protozoa detected. The high positivity rate of $G$. intestinalis found among those examined in this study suggests the need to adopt urgent measures to control and eradicate the transmission of pathogens in this community. The presence of nonpathogenic intestinal protozoa E. coli and E. nana is not a health problem, but indicates

Table 1

Occurrence of protozoans and pathogenic and nonpathogenic helminths in feces samples of children living on a 'landless farm workers' settlement in Araras, São Paulo State, in May 2005 and May 2006

\begin{tabular}{|c|c|c|c|c|}
\hline Parasites & $\begin{array}{l}\text { Children } 2005 \\
\quad(\mathrm{n}=29)\end{array}$ & $\%$ & $\begin{array}{l}\text { Children } 2006 \\
\quad(\mathrm{n}=14)\end{array}$ & $\%$ \\
\hline Giardia intestinalis & 28 & 96.6 & 09 & 64.3 \\
\hline Entamoeba coli & 08 & 27.6 & & \\
\hline Endolimax nana & 04 & 13.8 & 03 & 21.5 \\
\hline Hookworms & 02 & 6.9 & & \\
\hline Iodamoeba butschlii & 01 & 3.4 & & \\
\hline Ascaris lumbricoides & 01 & 3.4 & 01 & 7.1 \\
\hline Hymenolepis nana & 01 & 3.4 & & \\
\hline Strongyloides stercoralis & 01 & 3.4 & & \\
\hline Trichuris trichiura & 01 & 3.4 & & \\
\hline Negative & 01 & 3.4 & 02 & 14.3 \\
\hline
\end{tabular}


contamination by the fecal-oral route, leaving the subjects susceptible to pathogens. Due to the educational level of parents or guardians of the children, problems resulting from parasitic diseases and low weight can be solved by passing on information and knowledge to these families about the prevention and treatment of these diseases and the causes of giardiasis, and the need to improve basic sanitation and infrastructure, as most of the homes of the families have no electricity or running water. The presence of cysts in the samples analyzed during the two years indicates the need for health education in the region and the analysis of the quality of the water consumed which is probably contaminated with human and animal waste, infected largely by $G$. intestinalis cysts. The presence of domestic animals that can be infected with Giardia magnifies the problem. The participants presenting positive results for parasitic infection in the region is not only due to social issues, but mainly to the lack of infrastructure for basic sanitation. This situation is common in the urbanized periphery of cities. Children make use of polluted water, live in close proximity to garbage and perform their physiological needs outdoors, suffering with the transmission of intestinal diseases. We found that the social status of the individuals as well as housing conditions and level of hygiene are closely related to the test results. Data from literature show that the combination of measures such as sanitation and health education is the method of choice for reducing parasitic infections ${ }^{3}$. Indeed, a recent study ${ }^{2}$ using advanced statistical modeling to control individual and ecological potential confounders, demonstrated the impact on intestinal parasites of sanitation improvements implemented on a large population scale. They evaluated the impact of this intervention on the prevalence of A. lumbricoides, T. trichiuria, and G. duodenalis infections in preschool children, residents of Salvador in Northeast Brazil (a citywide sanitation intervention which began in 1996 aimed to raise the level of sewer coverage from $26 \%$ to $80 \%$ of households). They found the prevalence of $A$. lumbricoides infection was reduced from $24.4 \%$ to $12.0 \%$, T. trichiura from $18.0 \%$ to $5.0 \%$, and G. duodenalis from $14.1 \%$ to $5.3 \%$. Most of this reduction appeared to be explained by the increased coverage in each neighborhood by the sewage system constructed during the intervention. The implementation of measures for sanitation and hygiene education programs enable continuous improvement of the living conditions of children, and consequently an improvement in learning, development and alleviation of disease, and are highly necessary.

\section{CONCLUSION}

In this study the high positivity of giardiasis in child residents of the settlement was observed, even after treatment; adults were not sensitized to the study and did not collect and/or deliver children fecal samples; the precarious living conditions contribute to a high susceptibility to parasitic diseases and suggest that the treatment of the infected individuals without identifying and eradicating the means of contamination is simply a palliative measure.

\section{RESUMO}

\section{Alta ocorrência de giardíase em crianças do Assentamento Sem Terra, Araras, São Paulo, Brasil}

Enteroparasitoses continuam a ser um importante problema de saúde pública em muitas áreas ao redor do mundo, bem como no Brasil, e está frequentemente associada com a pobreza e à falta de saneamento básico. Pesquisa realizada em um ano revelou que 96,6\% (28/29) das crianças com idades entre quatro e 15 anos, recrutadas aleatoriamente no Assentamento Sem Terra em Araras, São Paulo, apresentaram cistos de Giardia intestinalis. Após o encaminhamento ao Posto de Saúde do bairro, todos receberam tinidazol, dose única de $50 \mathrm{mg} / \mathrm{kg}$. Após 12 meses, novas amostras de fezes foram coletadas e analisadas. Apesar da baixa adesão ao estudo, um percentual elevado (64,3\% - 9/14) de crianças permaneceu positivo para o protozoário. Este estudo mostrou alta positividade de giardíase nas crianças moradoras do assentamento, mesmo após o tratamento; indivíduos adultos não se mostraram sensibilizados com o estudo e não coletaram e/ou entregaram amostras fecais dos filhos; e o tratamento dos indivíduos infectados, sem identificação e erradicação das formas de contaminação, só funciona como medida paliativa.

\section{ACKNOWLEDGMENTS}

The authors thank Pablo Pultz for excellent technical assistance. RC was the recipient of a fellowship from PROPESq/UNIARARAS. None of the authors have a conflict of interest in respect to the present work. The contributions of the authors were as follows: conception, execution and design of experiments: OALJ, JK, RC; data analysis and drafting: RC.

\section{REFERENCES}

1. Arani AS, Alaghehbandan R, Akhlaghi L, Shahi M, Lari AR. Prevalence of intestinal parasites in a population in south of Tehran, Iran. Rev Inst Med Trop Sao Paulo. 2008;50:145-9.

2. Barreto ML, Genser B, Strina A, Teixeira MG, Assis AM, Rego RF, et al. Impact of a citywide sanitation program in Northeast Brazil on intestinal parasites infection in young children. Environ Health Perspect. 2010;118:1637-42.

3. Bóia MN, Carvalho-Costa FA, Sodré FC, Eyer-Silva WA, Lamas CC, Lyra MR, et al. Mass treatment for intestinal helminthiasis control in an Amazonian endemic area in Brazil. Rev Inst Med Trop Sao Paulo. 2006;48:189-95.

4. Cardoso GS, Santana ADC, Aguiar CP. Prevalência e aspectos epidemiológicos da giardíase em creches no Município de Aracajú, SE, Brasil. Rev Soc Bras Med Trop. $1995 ; 28: 25-31$.

5. de Carvalho TB, de Carvalho LR, Mascarini LM. Occurrence of enteroparasites in day care centers in Botucatu (São Paulo State, Brazil) with emphasis on Cryptosporidium sp., Giardia intestinalis and Enterobius vermicularis. Rev Inst Med Trop Sao Paulo. 2006;48:269-73.

6. Faust EC, Sawitz W, Tobie J, Odom V, Peres C, Lincicome DR. Comparative efficiency of various technics for the diagnosis of protozoa and helminth in feces. J Parasitol. 1932;25:241-62.

7. Ferreira P, Lima MR, Oliveira FB, Pereira MLM, Ramos LBM, Marçal MG, et al. Ocorrência de parasitas e comensais intestinais em crianças de escola localizada em assentamento de sem-terra em Campo Florido, Minas Gerais, Brasil. Rev Soc Bras Med Trop. 2003;36:109-11.

8. Gonçalves AL, Belizário TL, Pimentel Jde B, Penatti MP, Pedroso R dos S. Prevalence of intestinal parasites in preschool children in the region of Uberlândia, State of Minas Gerais, Brazil. Rev Soc Bras Med Trop. 2011;44:191-3.

9. Kobayashi J, Hasegawa H, Forli AA, Nishimura NF, Yamanaka A, Shimbukuro T, et al. Prevalence of intestinal parasitic infection in five farms in Holambra, São Paulo, Brazil. Rev Inst Med Trop Sao Paulo. 1995;37:13-8.

10. Lutz A. Schistosoma mansoni e a schistosomose, segundo observações feitas no Brasil. Mem Inst Oswaldo Cruz. 1919;11:121-5. 


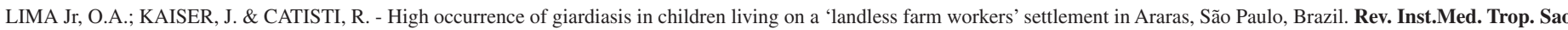
Paulo, 55(3): 185-8, 2013.

11. Menezes AL, Lima VMP, Freitas MTS, Rocha MO, Silva EF, Dolabella SS. Prevalence of intestinal parasites in children from public daycare centers in the city of Belo Horizonte, Minas Gerais, Brazil. Rev Inst Med Trop São Paulo. 2008;50:57-9.

12. Orlandi PP, Silva T, Magalhães GF, Alves F, Almeida Cunha RP, Durlacher R, et al. Enteropathogens associated with diarrheal disease in infants of poor urban areas of Porto Velho, Rondônia: a preliminary study. Mem Inst Oswaldo Cruz. 2001;96:621-5.

13. Pereira MGC, Atwill ER, Barbosa AP. Prevalence and associated risk factors for Giardia lamblia infection among children hospitalized for diarrhea in Goiânia, Goiás State, Brazil. Rev Inst Med Trop Sao Paulo. 2007;49:139-45.

14. Quadros RM, Marques S, Arruda AAR, Delfes PSWR, Medeiros IAA. Parasitas intestinais em centros de educação infantil municipal de Lages, SC, Brasil. Rev Soc Bras Med Trop. 2004;37:422-3.

15. Rouquayrol MZ, Almeida Filho N. Epidemiologia e Saúde. $6^{\text {a }}$ ed. Rio de Janeiro: Medsi; 2003

16. Saturnino ACRD, Nunes JFL, Silva EMA. Relação entre a ocorrência de parasitas intestinais e sintomatologia observada em crianças de uma comunidade carente de Cidade Nova, em Natal - Rio Grande do Norte, Brasil. Rev Bras Anal Clin. 2003;35:85-7.
17. Takizawa MG, Falavigna DL, Gomes ML. Enteroparasitosis and their ethnographic relationship to food handlers in a tourist and economic center in Paraná, Southern Brazil. Rev Inst Med Trop Sao Paulo. 2009;51:31-5

18. Tashima NT, Simões MJS, Leite CQF, Flumihan A, Nogueira MA, Malaspina AC. Classic and molecular study of Giardia intestinalis in children from a daycare center in the region of Presidente Prudente, São Paulo, Brazil. Rev Inst Med Trop Sao Paulo. 2009;51:19-24.

19. Valverde JG, Gomes-Silva A, De Carvalho Moreira CJ, Leles De Souza D, Jaeger LH, Martins PP, et al. Prevalence and epidemiology of intestinal parasitism, as revealed by three distinct techniques in an endemic area in the Brazilian Amazon. Ann Trop Med Parasitol. 2011;105:413-24.

Received: 1 November 2011

Accepted: 1 October 2012 